\title{
O herói político e o público
}

\section{Marta Brites Rosa}

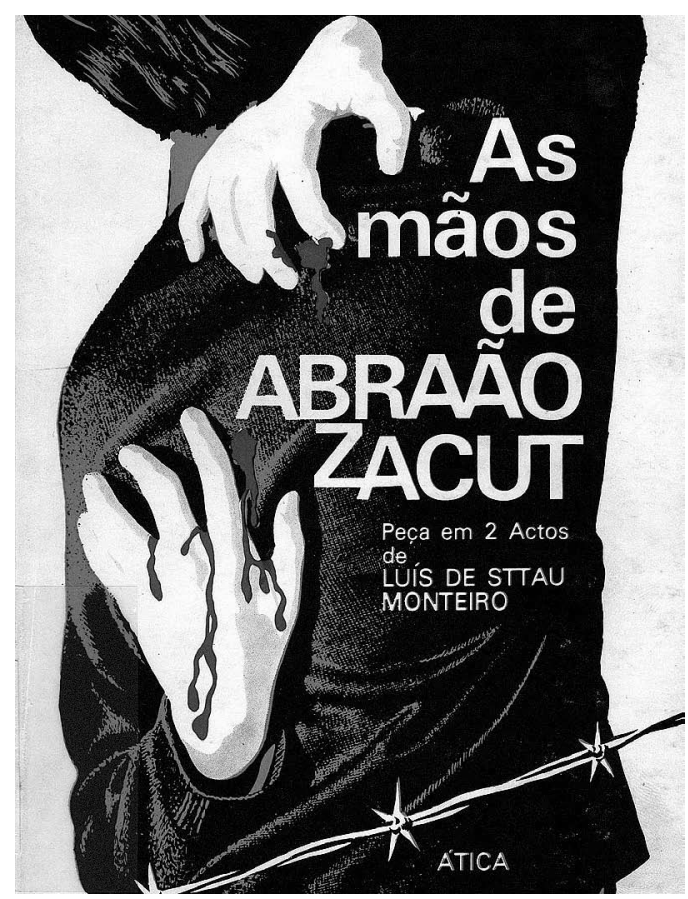

Quando hoje lemos ou assistimos à representação de uma peça historicamente datada, transportamos para essa leitura uma carga significativa tão grande que esperamos que a peça justifique todas as nossas pré-leituras e é dificil perceber que impacto a mesma peça teve num público virgem.

Em 1968, Sttau Monteiro publica a sua sétima peça de teatro, As mãos de Abraão Zacut. Todas as suas peças anteriores tinham sido alvo da censura: as editoras responsáveis pela sua publicação eram invadidas e os exemplares apreendidos ou proibida a sua venda e representação. As razões para essas proibições foram maioritariamente políticas, embora a linguagem obscena, a ridicularização das instituições religiosas e militares e a crítica acerada contra o regime político tenham contribuído generosamente para tal perseguição.

É sobre o público "virgem", que sofreu o primeiro impacto, que fez a primeira leitura da peça e Ihe atribuiu a carga histórica que agora tem, e a quem a mesma peça se dirigia, que nos vamos debruçar. Um público que era composto não só por espectadores, mas também por censores e jornalistas.

Esta peça foi escrita depois de Luís de Sttau Monteiro ter estado na prisão. Após a sua libertação, sentiu que era incapaz de prosseguir a sua vida sabendo que tantos outros continuavam presos. 0 que a peça retrata é isso mesmo: a impossibilidade de uns viverem livres enquanto

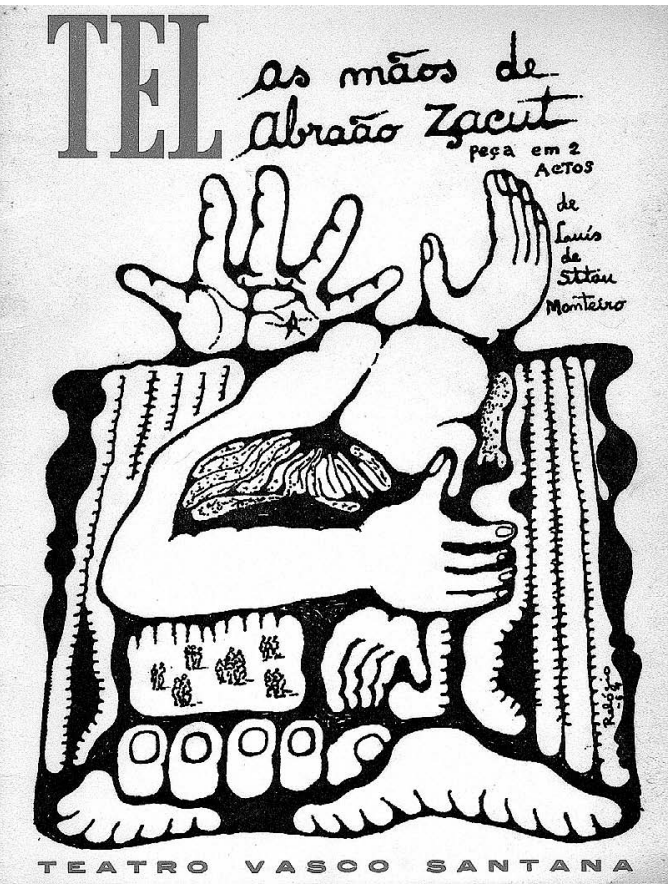

Capa da primeira edição de As mãos de Abraão Zacut, Lisboa, Ática, 1968

Capa do programa do espectáculo As mãos de Abraão Zacut, Teatro Estúdio de Lisboa, 1969

outros não têm essa mesma liberdade, bem como a degradação moral e social que surge quando é vital lutar pela sobrevivência (ou quando sobreviver é o único objectivo). David Levi é a personagem que irá encarnar esse dilema: vivo em liberdade enquanto outros morrem privados dela?

As mãos de Abraão Zacut passa-se num campo de prisioneiros. Vários indícios cenográficos e textuais conduzem aos campos de concentração nazis, sendo que todas as personagens da peça são judeus e foram aprisionadas por causa das suas crenças religiosas. Uma dessas personagens, Abraão Zacut, consegue motivar os outros prisioneiros a tentar a fuga de um deles. Esta tentativa resulta na evasão, de David Levi e na morte de Abraão Zacut. Uma vez em liberdade, David Levi sente-se angustiado pela situação dos outros prisioneiros e regressa à prisão, onde os procura motivar para uma nova insurreição e consciencializá-los da responsabilidade que têm perante a situação em que se encontram. Com dificuldade, consegue libertá-los da degradação espiritual e desalento e uma nova fuga é preparada, sem que o público conheça o seu desfecho.

A 18 de Dezembro de 1969 o Teatro Estúdio de Lisboa estreia a peça As mãos de Abraão Zacut. Trata-se da primeira peça de Luís de Sttau Monteiro a ser estreada com cortes mínimos antes do 25 de Abril. Contudo, apesar desta primeira aparência de abertura, existe por detrás
Marta Brites Rosa é Mestre em Estudos de Teatro e

investigadora do Centro de Estudos de Teatro da Universidade de Lisboa, colaborando no projecto da CETbase. 
um longo processo, registado sob o n. ${ }^{\circ} 8741$, da Inspecção dos Espectáculos do SNI (Secretariado Nacional da Informação, Cultura Popular e Turismo). Após uma primeira reprovação, em Agosto de 1968, a encenadora Luzia Maria Martins pede novamente autorização para a representar tendo o processo terminado em Novembro de 1969 (mais de um ano depois). Para a decisão final foi pedido que a peça fosse lida por vários membros da Comissão de Censura, o que resultou num dossier recheado de críticas e opiniões, que nos permite saber, de uma forma inequívoca, o valor que os censores atribuiam ao teatro político, a natureza dos itens que baniam e aqueles que eram considerados inofensivos.

As razões para a reprovação caem invariavelmente sobre a linguagem obscena, ofensas à religião cristã e instituições militares e aviltamento da condição humana. Há também as reprovações que afirmam que a temática da peça não se adequa à realidade portuguesa, nem à história nacional (argumento acompanhado geralmente por uma crítica positiva à estrutura dramática). No final dos relatórios, aponta-se a instigação à violência e o tom de contestação política e social, referindo que palavras como "liberdade, perseguição e cadeia" aparecem demasiadas vezes.

Por um lado, ao proibirem a representação, os censores admitem que o governo se torna um objecto possivel da crítica, validando os motivos para se falar em privação de liberdade; por outro lado, caso se recusassem a ver ali um ataque à política do governo coevo, seriam obrigados a aceitar a apresentação da peça. E este paradoxo, no final, é o motivo para a sua aprovação.

Apesar de uma passagem quase incólume pela censura foram enviados aos jornais pedidos de que não comentassem o teor político da peça. Na imprensa da época o espectáculo foi analisado segundo vários planos: encenação, direcção de actores, cenário, movimento, etc. No entanto, vários críticos sublinharam o valor político da peça como "susceptível de esclarecer o presente e estimular os contemporâneos a uma acção construtiva" (Rodrigues: 1970). Tratava-se do tal poder de incitamento que os próprios censores já tinham identificado. Porque nela se percebe que "o facho da batalha se transmite: quando tomba aquele que o sustenta, outro se ergue do exército das trevas para o render na luta dos oprimidos contra os opressores."; e ainda: "os carniceiro de Hilter (...) são todos os que ontem, ou hoje, desrespeitam e aviltam o seu semelhante, são as polícias políticas quando se tornam instrumento da degradação do Homem." Naturalmente, as polícias politicas aqui referidas são uma clara referência à PIDE. Há, portanto, uma identificação imediata entre o ambiente da peça e o ambiente histórico de Portugal em 1969.

A questão da recepção é fundamental na peça, porque se trata de um género que pretende interagir com o público, "movê-lo". Na mesma crítica ao espectáculo podia ler-se que "o público ouvia (...) aquilo que há muito desejava ouvir. Participava assim no espectáculo": o público entrava na sala de espectáculo como alguém que ignorava propositadamente o sofrimento dos outros; e saía transformado em soldado do mesmo exército de Abraão Zacut.

Outra crítica confirmava as opiniões anteriores: "a peça de SM pretende operar a transformação do espectador no actor que acaba de a 'escrever' na vida real (Jorge Strecht Ribeiro, Vértice)". Stretch Ribeiro reforçava que era a natureza positiva de David Levi que criava uma maior identificação e que era ele que conduziria o público ao mesmo destino do herói.

Abraão Zacut é uma personagem sem grandes características físicas ou psicológicas que não aquelas que o igualam a qualquer pessoa. Assim, se o Abraão Zacut da peça motivava as outras personagens, porque não seria ele capaz de motivar um público que se identificasse com aquelas sensações? Que também se encontrasse descontente, coarctado?

Foi esta questão que assustou os censores e que os levou a pedir a sua reprovação. Foi ela que originou a polémica com os que acreditavam no poder do espectáculo sobre o público português e temiam que este incentivasse a contestação política que já se vinha sentindo.

Mas a palavra de um dos censores, Geraldes Cardoso, sobrepôs-se, sendo que o seu argumento principal era o de que ao proibir aquela peça estar-se-ia a validar a identificação entre a estrutura da peça e as instituições portuguesas. Segundo ele, se o objectivo era demonstrar que Portugal era uma Democracia e que não havia repressão política, impunha-se permitir a apresentação da peça ao público. 0 censor acreditava também que, ao ser apresentada, ela perderia todo o seu valor de contestação.

Na sua entrada em cena, reconhecemos Abraão Zacut como alguém que é aprisionado sem razão, um pai, que 


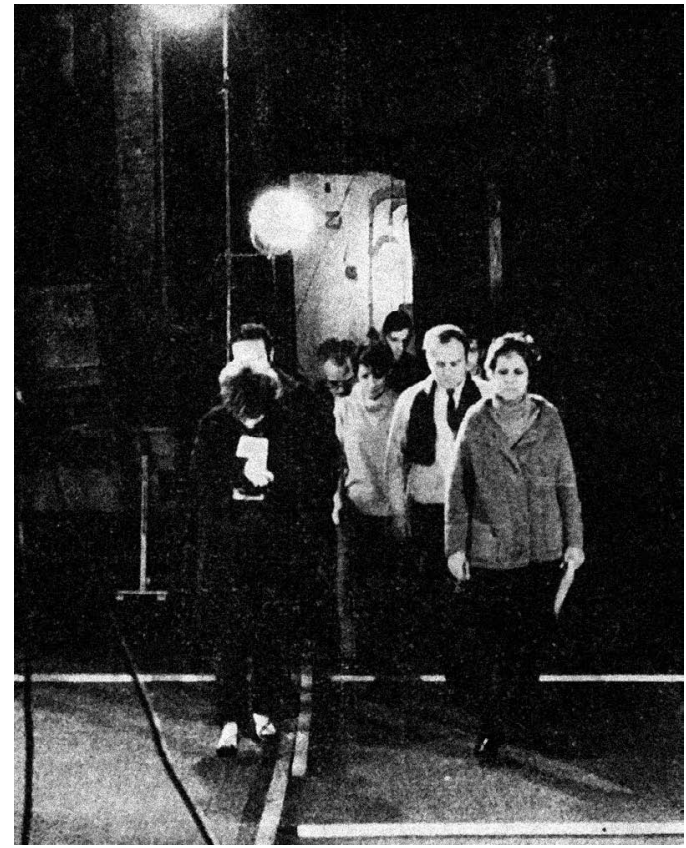

para salvar o filho, o nega como tal: facilmente identificamos que tipo de pessoa é aquela e aquilo por que passou. Os espectadores tinham conhecimento histórico para o fazer e também para reconhecer e identificar os breves episódios que são relatados pelas personagens: a história recente da perseguição dos judeus pelas forças nazis permitia reconhecer as emoções expressas no palco. Contudo, aquele público não se poderia identificar realmente com aquelas personagens, pois nenhum deles teria pessoalmente vivido aquela situação. Assim, os únicos sentimentos seriam empatia e compreensão.

A certa altura do espectáculo, o espectador leva o primeiro soco no estômago: uma personagem acusa as outras de não terem feito nada enquanto o mal não lhes tocou de perto. Antes não se preocupavam com os perseguidos, "enchiam as panças e iam fazer a digestão para o teatro" (Monteiro 1968: 90) - exactamente aquilo que o público está a fazer nesse momento. Pouco depois, após a narração do assassinio de uma criança de cinco anos pelos soldados, as personagens retomam a mesma imagem: "A esta hora os teatros estão a abarrotar de gente (...) gente como nós éramos". Temos nestas falas a primeira identificação das personagens com o público e o primeiro alerta para a possibilidade de um dia os espectadores se encontrarem naquela situação. Esta tirada não é um aviso para quem naquele momento está atrás da quarta parede, mas sim uma praga rogada com ódio. As personagens desejam a todas as pessoas que naquele momento assistem a espectáculos de teatro (e que ignoram propositadamente a situação dos oprimidos) que um dia também elas sejam aprisionadas, humilhadas, privadas da familia, vejam os filhos morrer, matem o seu semelhante para salvar a pele.

Desta forma, o presente, o instante actual em que público se encontra, é convocado para o palco e o espectáculo deixa de ser apenas um objecto para o qual se olha, mas um presente/futuro paralelo onde um dia o público se poderá encontrar.

A "praga" é uma estratégia dramatúrgica para aproximar rapidamente o público daquilo que as

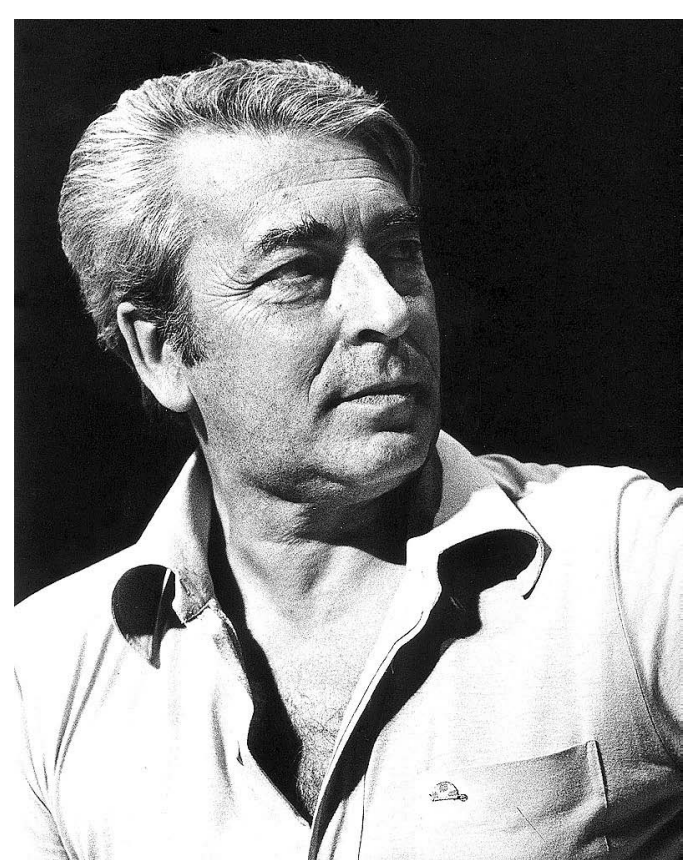

Ensaio de

As mãos de Abraão Zacut, Teatro Estúdio de Lisboa, 1969, reproduzida no programa do espectáculo.

personagens sentem no momento e de o "forçar" a agir por sentir na pele aquilo que não vive: o inconsciente da personagem não existe senão em relação directa com o investimento que o espectador efectua ao instalar-se ele mesmo dentro dessa realidade teatral. É por aqui que a representação produz um efeito poderoso sobre o espectador: a participação afectiva na vida da personagem, como se fosse sua, dispensando os esforços e os riscos com os quais seria confrontado se ele próprio se tivesse de a viver, mas permitindo teoricamente tomadas de decisão e de partido.

No acto II, é novamente retomada a interacção com o público: David Levi, em liberdade, recorda (em voz off) as frases anteriormente proferidas em relação aos públicos de teatro (representantes de todos aqueles que são indiferentes aos problemas dos outros, enquanto esses problemas não Ihes tocam pessoalmente). Uma personagem aponta directamente para o público e pergunta às outras personagens: "Vêem alguém capaz de arriscar um dia de vida seja por quem for? Não, não! Só quando chegar a vez deles serem presos é que abrem os olhos" (Monteiro 1968: 159).

Tudo isto se passou dentro do nivel da peça. Da peça para o público, apenas uns puxões de orelhas e uns abanões para abrir os olhos: foi duas vezes mencionado no palco, em ambas em tom irónico, negativo e ameaçador. Se houve relação entre os dois, não foi simpática, mas antagónica. 0 fruto deste antagonismo é a criação no público de uma possibilidade de perspectivar aquele mundo visto no palco, como o seu futuro próximo, se não fizer nada por si antes que seja tarde demais.

\section{Referências bibliográficas}

MONTEIRO, Luis de Sttau (1968), As mãos de Abraão Zacut, Ática, Lisboa. RIBEIRO, Jorge Strecht (1970), "C.I.T.A.C. - XII Ciclo de Teatro - As mãos de Abraão Zacut pela Companhia do Teatro Estúdio de Lisboa", Vértice, n. ${ }^{19}$, Março, pp. 253-254.

RODRIGUES, Urbano Tavares (1970), "Teatro autêntico - As mãos de

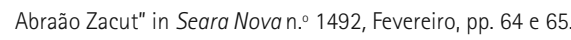

Luis de Sttau Monteiro, 1926-1993 [Arquivo do TNDMII, direitos reservados]. 